Dr. Arman Kirakossian is Ambassador Extraordinary and Plenipotentiary of the Republic of Armenia to Austria, Permanent Representative of the Republic of Armenia to the OSCE. He is author of books and more than 120 publications on the History of Diplomacy and International Relations among them British Diplomacy and the Armenian Question (Gomidas Institute, Princeton and London, 2003), The Armenian Massacres 1894-1896: U.S. Media Testimony (Wayne State University Press, Detroit, 2004), Armenia-USA: Current Realities and Vision for Future (Yerevan State University Press, 2007), and The Armenian Massacres 1894-1896: British Media Testimony (Armenian Research Center, University of Michigan, Dearborn, 2008)

\section{THE EXTERMINATION OF THE ARMENIANS \\ AND THE CONCEPT OF GENOCIDE IN CONTEMPORARY AMERICAN ENCYCLOPEDIAS}

Arman Kirakossian

The Armenian Genocide is an approved fact of history, a public knowledge which is recog nized not only by specialists but also by the international community. For more than forty years, the government of the Ottoman Empire succeeded in the cleaning out of the native-born Armenian population from not only the Armenian highland but also from the entire territory of the Empire by carrying out a genocidal policy of massacres and deportations, the culmination of which was the Genocide of the Armenians during the First World War. The crime committed by the Ottoman authorities towards the Armenian nation fully corresponds to the definition of the special convention of UN General Assembly in 1948 "On Prevention and Punishment of the Crime of Genocide" according to which "genocide means the acts committed with intent to destroy, in whole or in part, a national, ethnical, racial or religious group."

As a recognized public knowledge the Armenian Genocide is adequately and in a worthy manner represented in contemporary specialized encyclopedias, dictionaries, resource guides and handbooks published in the United States during the last fifteen years. The authors of the entries are leading specialists in the field of genocide studies. The analysis of this issues shows that the Armenian Genocide strengthened its position as a public knowledge and recognized fact of history.

According to Alan Whitehorn" "The Armenian Genocide is a reminder of the risks of not learning the lessons of history, the dangers of genocide denial, and the long-term negative consequences of allowing perpetrators to go unpunished. These were contributing factors to subsequent genocides. The knowledge of past genocides, such as the Armenian case, is a key to understanding and preventing future genocide. The mass slaughter of the Armenians was, however, instrumental in the birth of two important human rights concepts: 'crimes against humanity' and 'genocide'."'

Genocide is a twentieth-century concept for an age-old phenomenon, the killing of a defined population group. The word was coined during the Second World War by Raphael Lemkin, ${ }^{3}$ who "was looking for a word that would convey the full dimension of

1. Alan Whitehorn is a Professor at Royal Military College of Canada.

2. Alan Whitehorn, "Armenian Genocide." GenocideAwarenessandPreventionMonth2013, ABC-CLIO.Cf. http://www.historyandtheheadlines.abc-clio.com/ContentPages/ContentPage.aspx?entryId $=1797707$ \& currentSection $=1797513 \&$ productid $=61$.

3. Raphael Lemkin (1900-1959) was a Polish lawyer of Jewish descent, who lived in the United States from 1941. He is best known for his work against genocide, a word he coined in 1943. He first used the word genocide in print in Axis Rule in Occupied Europe: Laws of Occupation - Analysis of Government - Proposals for Redress (1944), and defined it as "the destruction of a nation or an ethnic group." 
the Nazi murder of Jews, though he also was deeply conscious of precedents, especially the killing of Armenians in 1915 and 1916 by the Young Turk government of the Ottoman Empire. Lemkin joined the Greek word for a group, 'genus', with the Latin suffix for murder, '-cide', to create the word genocide. He launched a one-man diplomatic campaign to convince the newly formed United Nations that it should develop a treaty that would outlaw genocide." ${ }^{4}$ Lemkin insisted upon the relationship between genocide and the growing interest in the protection of peoples and minorities that was manifested in several treaties and declarations adopted following World War I. He said there was a need to revisit international legal instruments, pointing out particularly the inadequacies of the Hague Convention of 1907, which he noted was "silent regarding the preservation of the integrity of a people." ${ }^{5}$ The General Assembly passed an initial resolution in favor of such a treaty in 1946, and the final Convention on the Prevention and Punishment of the Crime of Genocide was approved on 9 December 1948. It came into effect in January 1951 with the ratification by the requisite number of states. Since then, more than 140 states have signed the Genocide Convention.

The massacres and deportations of the Armenian population of the Ottoman Empire are qualified by the authors of the conceptual entries in the encyclopedias of Genocide, Death and Human Experience, Global Justice, Human Rights Issues Since 1945, Ethics, World's Minorities, Social Science, War Crimes and Genocide, Community, Human Rights, and The Oxford Handbook of Genocide Studies as a Genocide. In the Editor's Introduction of the Encyclopedia of Genocide one of the leading specialists in genocide studies Dr. Israel W. Charny ${ }^{6}$ listed the "the Armenian Genocide at the hands of the Turks" at the first place of the "past genocides in the twentieth century." In the Foreword to the same encyclopedia, the Most Reverend Archbishop Emeritus Desmond M. Tutu ${ }^{8}$ wrote: "And yet it is possible that if the world had been conscious of the genocide that was committed by the Ottoman Turks against the Armenians, the first genocide of the twentieth century, then perhaps humanity might have been more alert to the warning signs that were being given before Hitler's madness was unleashed on an unbelieving world." According to Encyclopedia of War Crimes

4. Eric D. Weitz, "Genocide." in The Social Science Encyclopedia, ed. Adam Kuper and Jessica Kuper (New York: Routledge, 2004, 2009), 409.

5. William A. Schabas, "Genocide," in Encyclopedia of Human Rights, vol. 2, ed. David P. Forsythe (New York: Oxford University Press, 2009), 295-296.

6. Dr. Israel W. Charny (born 1931, Brooklyn, New York) is an Israeli psychologist and genocide scholar, executive director of the Institute on the Holocaust and Genocide in Jerusalem, professor of Psychology and Family Therapy at the Hebrew University of Jerusalem, co-founder of the International Association of Genocide Scholars, editor-in-chief and executive director of GPN - Genocide Prevention Now.

7. Israel W. Charny, "Editor's Introduction to the Encyclopedia: The Dawning of a New Age of Opposition to Genocide," in Encyclopedia of Genocide, vol. 1, ed. Israel W. Charny (Santa Barbara, CA; ABCtion to Genocide,"

8. Tutu, Desmond Mpilo (born 1931, Klerksdorp, Transvaal) is a South African social rights activist and retired Anglican bishop, world known opponent of apartheid, was the first black Archbishop of Cape Town, received Nobel Peace Prize in 1984.

9. Desmond M. Tutu, "Foreword: Why is it Important to Learn about the Holocaust and the Genocides of All Peoples," in Encyclopedia of Genocide, vol. 1, ed. Israel W. Charny (Santa Barbara, CA; ABC- and Genocide "the campaign to exterminate the Armenian population and expel them from Ottoman Empire (which was superseded by Turkey) was so organized and systematic that it became a model for the prosecution of even more devastating genocidal programs later in the $20^{\text {th }}$ century." 10

Professors Donald Bloxham ${ }^{11}$ and A. Dirk Moses ${ }^{12}$ advocate in the Introduction of The Oxford Handbook of Genocide Studies that “...there is the tendency in university syllabi, textbooks, and the mantras of public commemoration of genocide to focus upon a few instances of genocide that, for a variety of reasons, have qualified for the canon of genera acceptance: alongside the Holocaust, Armenia, Cambodia, Rwanda, and the former Yugoslavia, and now Darfur tend to be included, but virtually no other cases." ${ }^{13}$

According to Michael R. Taylor (Encyclopedia of Death and Human Experience), "Genocide is the attempt to eradicate a people due to their race, religion, ethnicity, or nationality, usually by means of mass slaughter. The Holocaust, in which the Nazis murdered about 6 million Jews along with millions of others, is probably the most widely known genocide of the $20^{\text {th }}$ century. Although the Holocaust may be unique in other respects, it is not unique in its being genocide. Over the $20^{\text {th }}$ century and into the $21^{\text {st }}$ century, genocide has occurred in Cambodia, Germany, Iraq, Turkey, and Rwanda, and intervention has been rare. Some of these acts of genocide were probably preventable, and great harm might have been averted had the international community taken swift, decisive action."14

The author continues that "there is no known single motive or reason for genocide. The Nazis were motivated primarily by concerns for racial purity. The Khmer Rouge, responsible for the genocide in Cambodia in the latter half of the 1970s, were intent on creating what they took to be an ideal communist society, and they eliminated anyone they believed might obstruct this project. The genocide perpetrated by the government of Turkey in 1915 against its Armenian population was apparently motivated by concerns for national security, as was Saddam Hussein's genocide directed against the Kurds of Iraq. ... The government of Turkey, allied with Germany during World War I, suspected that some of Turkey's Armenians were aiding opposing powers. The Armenians were taken to pose a threat to nationa security, and their elimination was a way of resolving this issue."15

CLIO, 1999), LVII.

10. "Armenian Genocide," in Leslie Alan Horvitz and Christopher Catherwood, Encyclopedia of War Crimes and Genocide (New York: Facts on File, 2006), 25

11. Donald Bloxham is a Professor of Modern History at Edinburgh University, editor of the Journal of Holocaust Education

12. A. Dirk Moses is the Chair of Global and Colonial History at the European University Institute, Floence, and the editor-in-chief of the Journal of Genocide Research.

13. Donald Bloxham and Dirk A Moses, "Editors' Introduction. Changing Themes in the Study of Genocide," in The Oxford Handbook of Genocide Studies, ed. Donald Bloxham and Dirk A Moses (New York: Oxford University Press, 2013), 4.

14. Michael R. Taylor, "Genocide," in Encyclopedia of Death \& the Human Experience, vol. 1, ed. Clifton D. Bryant and Dennis L. Peck (Thousand Oaks, California: Sage Publications, 2009), 508.

15. Ibid, 509 . 
According to Yves Ternon ${ }^{16}$ (Encyclopedia of Genocide) "Coined in the twentieth century, the word genocide denotes a crime of exceptional gravity, the most extreme violation of the rights of man: denial of the right to live to many people. In order to understand this complex phenomenon, a comparative and multidisciplinary approach is mandatory. Though such a crime can be ancient, new characteristics in the recent century have given it its specificity. Perpetrated by the state, the crime consists in the destruction of a community of its own citizens or of those of a country it occupies. Implementation foes unhindered when the state exerts unlimited control over decisions and means of action while wielding exclusive authority in all branches of government, in other words when the state has reached a higher degree of totalitarianism. The motive for genocide is based on a creed which, however absurd, holds sufficient sway to convince and waive any moral inhibitions of those called upon to perpetrate the crime. The creed thus propagated rests on the presumption that one's very existence is menaced. A fictitious menace is serves nonetheless as a pretext to genocide, the ultimate means of getting rid of the targeted victims. Contrary to war conditions wherein belligerents have, more or less, the means of reciprocal destruction, the implementation of genocide imposes an overpowering state on a powerless community devoid of the means of self-defense and much less still of inflicting harm, literally speaking an 'innocent' community.

The twentieth century has witnessed the emergence of the most basically criminal regime in contemporary history: national-socialism (Nazism), build upon hatred, scorn and brutal force, rooted in an absurd ideology, the ingredients of which are racism, social-Darwinism and anti-Semitism. Such 'negative dialectics' through a natural though devious process brought about the annihilation of the Jews in Europe during the Second World War, the unsurpassed crime of the twentieth century. Related to it stands the genocide of the Gypsies, less thorough and perhaps based on a less pervasively blind hatred-here the Nazis claimed they sought the elimination of the 'drop-outs' of society.

The uniqueness of the genocide of the Jews, with its specific and exclusive characteristics in this century doesn't, however, preclude the use of the term genocide in qualifying other crimes. One notes perhaps in particular the annihilation by the Union and Progress Party, at the head of the Ottoman government in the years 1915-1916, of the Armenian communities then living in Ottoman Empire. This genocide was also perpetrates as a 'final solution' to a problem which had gone unsolved for 40 years." 17

"Regarded as the ultimate crime and the gravest possible violation of human rights, -written in the entry Genocide of the Encyclopedia of Human Rights Issues since 1945, genocide occupies a prominent place in human history, including twentieth-century history. In 1915, for example, the Ottoman Turks conducted the systematic extermination of over an estimated 1 million Armenians. During World War II, through forced labor, sterilization, starvation, gassings and muss murder in concentration camps, some six million Jews, along with an uncertain number of homosexuals, Roma people (Gypsies), and others were killed

16. Yves Ternon (born in 1932, France) is a French physician and medical historian, an author of historical books about the Jewish Holocaust and the Armenian Genocide, Professor of the History of Medicine at University Paris IV Sorbonne.

17. Yves Ternon, "The Twentieth Century: A Century of Genocide," in Encyclopedia of Genocide, vol. 2, ed. Israel W. Charny (Santa Barbara, CA; ABC-CLIO, 1999), 562-563. by Nazi Germany. In the case of the Jews, the effort was designed to effect the Final Solution (from the standpoint of Nazis) to their undesirable and undeserved presence in Europe It was the reaction of the global community to the killing of the Jews that prompted the United Nations to adopt the Convention on the Prevention and Punishment of the Crime of Genocide in 1948.

Since 1945, there have been repeated examples of genocide: the killing of Cambodians during the Pol Pot regime; the Indonesian slaughter of the people of East Timor; and most recently, the occurrences in Rwanda and the former Yugoslavia." 18

According to Javaid Rehman ${ }^{19}$ (Encyclopedia of the World's Minorities), "the term genocide means the killing of a race, a tribe, or a religious or ethnic group. Genocide as an unfortunate phenomenon of physical extermination of a minority group has remained part and parcel of human history. However, it was only after the genocidal acts committed by the Nazis during World War II that genocide was condemned as an international crime. In 1948 the United Nations adopted the Convention on Prevention and Punishment of the Crime of Genocide, which condemns genocide and prohibits its exercise in times of war and peace. The condemnation of genocide has recently been reaffirmed by the Statute of the Internationa Criminal Court (1998). Although genocide is now universally condemned as an international crime, there are substantial concerns about the continuing exercises of genocidal activities within contemporary societies. Many minorities and groups live under the shadow of extinction; some continue to suffer from physical destruction, partially if not completely...

Genocide has been practiced since the beginning of human history. Many tragic instances of genocide could be recounted. These would include the horrifying massacres resulting from Assyrian warfare during the seventh and eighth centuries BCE and the Roman obliteration of the city of Carthage and all its inhabitants. Religion has been used as a weapon for generating intolerance and for the ultimate destruction and genocide of religious minorities. Within the texts of religious scriptures, various forms of genocide of religious minorities are sanctioned. The tragic wars of the medieval period and the Middle Ages, the crusades, and the Jihads (Islamic holy wars) translated these religious ordinances to complete and thorough use. Many of the contemporary genocidal conflicts are based around religious supremacy. The process of colonization resulted in the extermination and genocide of indigenous and colonized peoples. More recently, during the nineteenth and twentieth centuries the mechanism of genocide has been practiced on a very wide scale. Thus, the Armenian genocide conducted by the Ottoman Turks between 1895 and 1896 in the massacres of nearly 200,000 Armenians. The Turks repeated this practice of genocide of the Armenian people during World War I. The rise of nationalism and totalitarian ideologies such as Nazism and Stalinism and the upsurge of racial, religious, and linguistic extremism in the twentieth century generated wholesale extermination of minorities. The crimes of physical extermination conducted by the Nazis against the Jewish population in Europe were of unparalleled gravity." 20

18. "Genocide" in Encyclopedia of Human Rights Issues Since 1945, ed. Winston E. Langley (London, Chicago: Fitzroy Dearborn Publishers, 1999), 133.

19. Javaid Rehman is a Professor of Law at the Brunei University, London.

20. Javaid Rehman, "Genocide," in Encyclopedia of the World's Minorities, ed. Carl Skutsch (New York: 
Each genocidal act is based on ideology, an important part of the process in society that leads to the tragedy of the victim nation. These ideologies vary in form or content but usually have certain structures in common with others that support genocide, and they all serve certain common functions for the dominant race, group and its members. The entry of Ervin Staub ${ }^{21}$ in the Encyclopedia of Genocide is dedicated to the ideology of genocide: "An ideology is a conception of social arrangements in a society or in the world that for the creators of the ideology are the desirable, ideal forms of life. There are nationalist ideologies, which focus on the wealth, power, influence and frequently also the purity of a group or nation; and "better world" ideologies, like communism, which offer a version of ideal social arrangements for all humanity.

Many ideologies are destructive, potentially genocidal, in that they identify enemies who supposedly stand in the way of the ideology's fulfillment. These enemies must be 'dealt with' if the ideology is to be fulfilled. Sometimes the intention to kill them is present from the start. More often, there is no intention or fully formed intention to kill them, but discrimination and limited violence against the opponents, nonbelievers and outsiders lead to changes in perpetrators and to an evolution of increasing violence that ends in genocide.

Genocidal ideologies can have both nationalist and bitter-world elements. For example, the Nazi ideology included the concept of 'lebensraum' or living space, the right of Germans to more territory, clearly nationalist in nature. It also included the concept of the purity of race. While its focus was the protection of Germans from Jews, Gypsies, and others, even genetically inferior Germans, it implied that by eliminating the contamination of higher races by lower ones all the higher races would be improved. The 'auto genocide' in Cambodia was based on a vision of total social equality derived in part from communism, but had nationalistic building blocks and elements. The genocide of the Armenians in Turkey was shaped by a 'pan-Turkish,' nationalistic ideology. The violence in Bosnia was based on a combination of fear, hate and ambition that manifested itself in a primarily nationalistic form.

Why do people turn to such destructive ideologies? They often do so in response to difficult social conditions and the frustration of basic human needs, fear and confusion. Having a positive vision of the future provides a comprehension of reality and hope in place of the chaos and confusion of the present. It helps people unite, at a time they feel alone and isolated. It provides them with purpose and meaning, at a time they feel helpless and not in control of their lives. People do need visions of a hopeful future in such difficult times. Unfortunately, the culture, past history and the conditions of life generate forces for the creation of visions that identify enemies. Scapegoating some group, identifying it as responsible for life problems, provides an explanation for the difficult conditions of life, and makes people feel better about themselves. Pointing to enemies also brings people together, help them unite. The group's culture often includes a history of devaluation of the group that becomes the scapegoat and ideological enemy (the Jews, the Armenians), or a historical rift (between the people in the cities and in the countryside in Cambodia). At

Routledge, 2005), 493.

21. Ervin Staub has taught at Harvard University and the University of Massachusetts at Amherst. times the difficult conditions themselves arise from conflict and enmity with another group or there is a history of mutual antagonism between the two groups (like Hutus and Tutsis in Rwanda and Burundi). Long-standing traditions of dehumanization and antagonism can be greatly and seedily intensified and catapulted into frenzied extremes relatively easily and in amazingly short periods of time by propaganda campaigns, for example, Hitler's repeated documentations of the Jews in contexts of majestic public events accompanied by stirring pageantry and marital spirit. There was an extensive state-run radio campaign against the Tutsi preceding the Rwanda Genocide in 1994.

As the dehumanization effect escalates, another mechanism of attribution of evil intention and demonic powers to the intended victim people also comes into stronger play. In the end, the implicit or explicit message becomes that the other people must be killed first in order to saves one's own people from destruction. The combination of dehumanization-they are not human beings like us and are outside of our moral universe of obligation to protect human life- and attribution of dangerous demonic intent and strength provides a powerful basis for an ideology of genocide: they deserve to be and must be eliminated."22

Continuing the ideological aspect of genocide Eric D. Weitz ${ }^{23}$ notes (The Social Science Encyclopedia): “...Genocides take on truly massive proportions when racism or extreme nationalism becomes the guiding principles of the state (though not all racial states engage in genocide: witness South Africa and the Jim Crow USA). The infamous, though not exclusive, examples are the late Ottoman Empire under the Young Turks, Nazy Germany, the former Yugoslavia and Rwanda. In all of these instances, the state promised its followers a future of unbounded happiness and prosperity once the supposed enemy group - Armenians in the Ottoman Empire, Jews in Third Reich, Croats and Muslims in Yugoslavia, Tutsis under a radical Hutu government - was eliminated. At the same time, moderate members of the dominant group who opposed the genocides were also killed. No genocide occurs divorced from other human rights violations." ${ }^{24}$

There are many examples of genocides in the world history. We read about them in the Social Science Encyclopedia: "Some of the earliest cases occur in the Bible. The Book of Joshua records numerous instances in which the Israelites completely destroy the populations they encounter. The Roman destruction of Carthage is often cited as another case. But in the modern period, genocides became more systematic, more widespread and more deadly In the twentieth century, genocides were produced mostly by states that sought to create homogeneous populations of one sort or another. They are part of revolutionary drives to remake the social order, to 'purify' the population of groups, conceived in racial, nationa or religious terms, which hold on to different ways of life and are demonized as the enemies that threaten the well-being of the dominant group. Genocides are terribly violent acts that entail high levels of face-to-face brutality. They are never antiseptic, factory-like processes of death, not even in the Holocaust. While modern genocides are typically initiated by

22. Ervin Staub and Israel W. Charny, "Ideology of Genocide," in Encyclopedia of Genocide, vol. 2, ed Israel W. Charny (Santa Barbara, CA; ABC-CLIO, 1999), 347-349.

23. Eric D. Weitz is the Dean of Humanities and Arts and Professor of History at City College, City University of New York.

24. Eric D. Weitz, “Genocide,” 410-411. 
states, they require the mobilization of substantial segments of the population to carry out the work of killing...

..Most modern genocides have occurred in the context of war or vast domestic upheaval, when old rules no longer apply and conditions of instability both heighten the sense of insecurity and open up visions of great transformations, of finally laying to rest internal social divisions and creating a prosperous, harmonious future. The First World War was the landmark event because it created a culture of killing and revealed what highly organized states could accomplish. It is no surprise that the first modern genocide, that of the Armenians, occurred in context of total war when the Young Turk rulers were threatened by the Allied powers and demonized the Armenian population as traitors. At the same time, the Young Turks imagined a vast, homogeneous pan-Turkic empire, which could only be accomplished, they believed, through the deportation and massacres of Armenians. Similarly, Jews in Nazi Germany were subject to the most severe discrimination in the 1930s, but it was only in the context of total war that the Nazis unleashed the Holocaust.

Three kinds of genocides emerged in the modern period: (1) colonial genocides, (2) genocides as by-products of more general and massive violations of political and social rights, and (3) genocides in which mass killings based on ethnicity, nationality, religion or race move to the very core of state policies..."25

According to William A. Schabas ${ }^{26}$ "The paradigm of modern genocides is of course the Nazi Holocaust or Shoah, the partially successful attempt to exterminate the Jews of Europe. In the twentieth century three other manifestations of genocide stand out: the attack on the Herero people by German colonialists in German Southwest Africa (now Namibia) in 1904, the massacres of the Armenians by the Ottoman Turkish regime in 1915, and the attempted extermination of Rwanda`s Tutsi population by racist extremists in 1994."27

As it was mentioned before, the term "genocide" was created by Polish jurist Raphael Lemkin as a term to define the mass killing of Jews by the Nazis in the Second World War and the mass killing of the Armenians by the Ottoman authorities during the First World War. In both cases, the mass killing took place within the context of a more general war, and Lemkin thought of genocide as a type of warfare. According to Jerry Fowler (Encyclopedia of Community, From the Village to the Virtual World) "Already familiar with the Ottoman campaign of murder and deportation against the Armenians that began in 1915, he [Lemkin] understood the murderous implications of Nazi ideology much sooner than most of his contemporaries." 28

Although the term was introduced by Lemkin "...most immediately in reaction to the Nazi 'Final Solution' directed against the Jews, but it was also meant to identify that crime more generally as the annihilation or attempted annihilation of the members of the group

\section{Ibid, 409-410.}

26. William A. Schabas (born 1950) is a Canadian academic in the field of international criminal and human rights law, Professor of International Law at Middlesex University, Professor of International Human Law and Human Rights at Leiden University, an internationally recognized expert on human rights law, genocide, and the death penalty, President of the International Association of Genocide Scholars from 2009-2011.

27. William A. Schabas, "Genocide," 294.

28. Jerry Fowler, "Genocide," in Encyclopedia of Community: From the Village to the Virtual World, vol. 1, ed. Karen Christensen and David Levinson (Thousand Oaks, CA: Sage Publications, 2003), 540-541. (genos) solely because of group association. Lemkin, a lawyer and himself a Polish-Jewish refugee, had previously (at the Fifth International Conference for the Unification of Penal Law, Madrid, 1933) unsuccessfully proposed international recognition of the crime of 'barbarity' - 'oppressive and destructive actions directed against individuals as members of a national, religious, or racial group.' ...Lemkin expanded the concept of genocide to include attacks on political, economic, and cultural groups; in addition to the Nazi campaign of annihilation, he cites among earlier instances of such attacks the Roman destruction of Carthage (146 B.C.E.), the conquest of Jerusalem by Titus (C.E. 72), and the Turkish massacre of the Armenians (1915-1917). The crime of genocide, he claims, extends beyond the attacks on civilian populations in 'occupied' territory that had been addressed and in some measure guarded against in international law by the Hague Conventions. The designation of groups as targets for destruction, in Lemkin's view, expands the possible rationale (and thus the threat) of systematic killing." 29

According to Sally J. Scholz ${ }^{30}$ "In his 1944 work Axis Rule in Occupied Europe, Raphael Lemkin coined the word "genocide" in order to designate the scale of atrocities that he had spent much of his adult life fighting. Lemkin combined the Greek word for people, race, or tribe with a word derived from Latin meaning "to kill". His aim was to identify the mass scale atrocity that targets a people. He recognized that planned and coordinated destruction of a people or a nation aims not solely or even primarily at outright killing but also at the destruction of culture, language, traditions, and social and political infrastructures.

The genocide that inspired Lemkin to fight for international laws barring acts that intend to destroy a nation or people, is the Armenian genocide during World War I. On April 24, 1915, the Turks of the Ottoman Empire began rounding up thousands of Armenians and forcibly exiling them in a campaign that has come to be recognized as the firs major genocide of the modern era. It is estimated that one and a half million Armenians were systematically killed by the military or starved while on the forced marches out of the Ottoman Empire..."”

The editor-in-chief of the Journal of Genocide Research A. Dirk Moses writes in The Oxford Handbook of Genocide Studies that "The genocide concept is also the culmination of a long tradition of European legal and political critique of imperialism and warfare against civilians. All of the instances about which he [Lemkin] wrote for his projected world history of genocide occurred in imperial contexts or involved warfare against civilian populations. Most of his [Lemkin] case studies from the Eurasian land mass were taken from continental empires: the Roman Empire, the Mongols, the Ottoman Empire, Charlemagne and the spread of German peoples eastwards since the Middle Ages. Here is a typical statement from an article in the Christian Science Monitor in 1948: 'The destruction of Carthage, the destruction

29. Berel Lang, "Genocide," in Encyclopedia of Ethics, ed. Lawrence C. Becker and Charlotte B. Becker (New York: Routledge, 2011) 607

30. Sally J. Scholz (born 1968) is a Professor of Philosophy at Villanova University and editor of Hypatia: A Journal of Feminist Philosophy. Her research focuses on social and political philosophy, feminis theory, violence against women in conflict settings, war rape and war theory.

31. Sally J. Scholz, "Genocide," in Encyclopedia of Global Justice, vol. 1, ed. Deen K. Chatterjee (New York: Springer, 2011), 387. 
of the Albigenses and Waldenses, the Crusades, the march of Teutonic Knights, the destruction of the Christians under the Ottoman Empire, the massacres of the Herero in Africa, the extermination of the Armenians, the slaughter of the Christian Assyrians in Iraq in 1933, the destruction of the Maronites, the pogroms of Jews in Tsarist Russia and Romania - all these are classical genocide cases (Lemkin, Raphael. War against Genocide. In: Christian Science Monitor, 31 January 1948)." "32 The author continues further that "'Barbarity' and 'Vandalism' are of relevance for genocide because of their focus on group protection. He [Lemkin] had been indignant that the Turkish perpetrators of the Armenian deportations and massacres were able largely to escape prosecution, and appalled by the massacres of the Assyrian Christians in Iraq." 33

Prior to 1945 there had been other recognitions of crimes against humanity or crimen contra omnes. In 1915 the governments of Great Britain, France, and Russia condemned massacres of Armenians by Turks as "crimes against humanity and civilization." ${ }^{34}$ William A. Schabas writes in The Oxford Handbook of Genocide Studies: "Even prior to Lemkin's time, international law recognized a limited number of so-called international crimes. As a general rule, they were so designated not because of their shocking scale and extent but for more mundane reasons, namely, because they escaped the territorial jurisdiction of states; piracy is the classic example, a crime committed on the high seas. Other examples include trafficking in women, damaging submarine cables, and offenses relating to drugs, counterfeit currency, and pornography. In the early twenty-first century these would be more likely described as transnational crimes. Lemkin and others argued from a different perspective, proposing the recognition of international crimes where these represented serious human rights violations. The emphasis was not so much on the international dimension of their perpetration as on the scale or horror of the acts. Such crimes tended to escape prosecution not because of international difficulties in enforcement but because the state where the crime took place was unwilling to prosecute, generally because its government was complicit in the acts.

The beginnings of this new vision of criminal justice were already apparent at the time of World War I, when Britain, France, and Russia warned that they would hold perpetrators to account for 'these new crimes of Turkey against humanity and civilization.' But the idea that a state and its leaders could be held accountable for atrocities committed against their own nationals remained extremely controversial, and it was this lacuna in the law that Lemkin worked to fill." ${ }^{35}$

According to Michael J. Bazyler" ${ }^{36}$ (Encyclopedia of Genocide)"The term 'crimes against humanity' was first utilized in international law in the 1915 joint declaration of Great Britain, France and Russia in response to the massacres of the Armenian population

32. A. Dirk Moses, "Lemkin, Culture, and Concept of Genocide," in The Oxford Handbook of Genocide Studies, ed. Donald Bloxham and A. Dirk Moses (New York: Oxford University Press, 2013), 25-26.

33. Ibid, 30-31.

34. Jordan J. Paust, "Crimes Agaist Humanity," in Encyclopedia of Human Rights, ed. David P. Forsythe (New York: Oxford University Press, 2009), 421.

35. William A. Schabas, "The Law and Genocide," in The Oxford Handbook of Genocide Studies, ed. Donald Bloxham, and A. Dirk Moses (New York: Oxford University Press, 2013), 124

36. Michael J. Bazyler is a Professor of Law at Whittier Law School in Costa Mesa, California. in Ottoman Empire. The term was formally defined by the Nuremberg Charter, during the prosecution of the Nazi war criminals. Article 6(c) of the Charter defines crimes agains humanity as 'murder, extermination, enslavement, deportation, and other inhumane acts committed against any civilian population, before or during the war, or persecutions on political, racial or religious grounds in execution of or in connection with any crime within the jurisdiction of the Tribunal, whether or not in violation of the domestic law of the country where perpetrated'." 37

The Encyclopedia of War Crimes and Genocide notes: "The earliest use of the term is found in the Hague Convention of 1907, although it is based in CUSTOMARY LAW during armed conflict. That is to say, the codified law pertaining to crimes against humanity evolved from principles and values that have gained almost universal acceptance throughout history. Even though most international agreements in the early years of the $20^{\text {th }}$ century covered the conduct of armed parties to a conflict, there were exceptions, notably the forced deportations and massacres of Armenians by Ottoman Turks in 1915, which involved the use of military force against an unarmed civilian population. A commission established in 1919 found that Turkish officers had in fact been culpable of "crimes against the laws of humanity' for their treatment of the Armenians, yet both the United States and Japan opposed the criminalizing of these acts because they were violations of moral law." ${ }^{\prime 38}$

Benjamin Lieberman ${ }^{39}$ believes that "the persecution of Armenians during the First World War incorporated many of the chief features of ethnic cleansing. ...In this case ethnic cleansing led to genocide." ${ }^{40}$

Summarizing the abovementioned, we conclude that in their entries the leading specialists in genocide studies not only qualify the massacres and deportations of the Armenian population of the Ottoman Empire during the First World War as genocide but also consider this historical fact as a crime which became a precedent for the creation and development of the genocide concept.
37. Michael J. Bazyler, "Crimes Against Humanity," in Encyclopedia of Genocide, vol. 1, ed. Israel W. Charny (Santa Barbara, CA; ABC-CLIO, 1999), 153-154.

38. "Crimes against Humanity," in Encyclopedia of War Crimes and Genocide, ed. Leslie Alan Horvitz and Christopher Catherwood (New York: Facts on File, 2006), 110.

39. Benjamin Lieberman is a Professor of History at Fitchburg State College (MA, USA). His research focuses mainly on the concept of ethnic cleansing.

40. Benjamin Lieberman, “'Ethnic Cleansing’ Versus Genocide?,” in The Oxford Handbook of Genocide Studies, ed. Donald Bloxham and A. Dirk Moses (New York: Oxford University Press, 2013), 50. 